\title{
Drugs Errors in Anaesthesia Practice: Four Cases of Non-Fatal Morbidity
}

Jose LLagunes Herrero, M.D., Carmen Reina, M.D., Lucrecia Blasco, M.D., Esperanza Fernandez, M.D., Miguel Plaza, M.D., Eva Mateo, M.D.

\section{INTRODUCTION}

Drugs used in anesthesia produce rapid effects on the respiratory and circulatory systems. Administration errors involving these drugs can have potentially severe effects on patients. Drug mistake as it represented a small part of anesthesia problems but it still has the potential for serious morbidity. In the retrospective study of Yamamoto et al. ${ }^{1}$ during eight years, 233 incidents were reported in a total of 27,454 anesthesia cases.

The total frequency of medication errors in the survey period was $0.175 \%$ (48 incidents). The most frequent error was overdose and substitution. Incidence in the prospective study of Fasting and Gisvold ${ }^{2}$ with 55,426 procedures reported that drug errors occurred in $0.11 \%$ (63 cases). In the study of Webster et al. ${ }^{3}$ with 7,794 patients the incidence of a drug administration error was $0.75 \%$ (58 cases). The identification of adverse drug events as threats to patient safety in anesthetics practice is a major step forward ${ }^{3,4}$.

Enhancing working relationships among anesthesiologists, pharmacists and nurses is crucial for safe medication practices in operation theatre (OT) setting. Coupled with the above, using critical incident reports to investigate cause and origin errors will improve the system to make it safer. We report four cases of unusual medical errors (ME) in the OT without harm to the patient, and how their analysis and identification prevented more serious damage to occur.

\section{CASE REPORTS}

Case 1 - A 76-year-old man, 78 kg, suffered a cardiac surgical process (coronary artery bypass grafting). He was standard monitorized with ECG, NIBP, $\mathrm{SpO}_{2}$ and catheterized with a peripheral vein and an arterial line before the anesthetic induction. After giving midazolam $1 \mathrm{mg}$, a few seconds later he showed unconsciousness and apnea with drop in $\mathrm{SpO}_{2}$ to $88 \%$. Immediately he was ventilated with $100 \% \mathrm{O}_{2}$, and 30 seconds later the patient was awake and with adequate spontaneous ventilation. Anesthesia was induced and surgical procedure was completed successfully.

Case 2 - A 68-year-old woman, $65 \mathrm{~kg}$, scheduled for cardiac surgical procedure (valvar mitral repair). In the operation theatre she was standard monitorized and catheterized with a venous and arterial line before the induction of anesthesia. The patient was given midazolam $2 \mathrm{mg}$, and a few 
seconds later she developed unconsciousness and apnea with a drop in oximetry $\left(\mathrm{SpO}_{2}\right)$ to $90 \%$. Immediately she was ventilated with $100 \% \mathrm{O}_{2}$, and 40 seconds later the patient was awake and with good spontaneous ventilation. She was induced as usual and surgical procedure was completed effectively.

Case 3 - A 66-year-old man, $75 \mathrm{~kg}$, suffered a cardiac surgical procedure (Coronary Arterial Bypass Grafting). In the operation room he was standard monitorized and catheterizated with a venous and arterial line before induction of anesthesia. The patient was given midazolam $1.5 \mathrm{mg}$, and few seconds later he also developed unconsciousness and apnea with drop in $\mathrm{SpO}_{2}$ to $86 \%$. He was rapidly ventilated with $100 \% \mathrm{O}_{2}$, and few seconds later the patient was awake and with effective spontaneous ventilation. Anesthesia was induced and the surgical procedure was completed fruitfully.

Case 4 - An 83-year-old man, $85 \mathrm{~kg}$, experienced a cardiac surgical procedure (CABG). In the operation theatre he was standard monitorized, $\mathrm{O}_{2}\left(3\right.$ L. $\left.\mathrm{min}^{-1}\right)$ was administered with a nasal cannula and he was catheterized with a venous and arterial line before the induction of the anesthesia. During the procedure the patient was given midazolam $1 \mathrm{mg}$, a few seconds later he developed unconsciousness and apnea with drop in $\mathrm{SpO}_{2}$ to $80 \%$. Immediately he was ventilated with $100 \% \mathrm{O}_{2}$ but he had stiffness and it was impossible to ventilate. Anesthesia was induced with succinylcholine $1 \mathrm{mg} \cdot \mathrm{kg}^{-1}$ and the trachea was intubated without problems; After this he recovered the ventilation spontaneously, and he was given cisatracurium $0.2 \mathrm{mg} \cdot \mathrm{kg}^{-1}$ and hypnosis was reached with sevoflurane. Surgical procedure was completed successfully and postoperative was normal.

\section{DISCUSSION}

In all four cases there was suspicion about a medication error, and in the first step we thought the drug implicated was midazolam because of wrong drug concentration: instead of $1 \mathrm{mg}$ per $\mathrm{mL}$ it was supposed to be $5 \mathrm{mg}$ per $\mathrm{mL}$. But in OT there were not midazolam in vials of $3 \mathrm{~mL}$ with $15 \mathrm{mg}\left(5 \mathrm{mg} \cdot \mathrm{mL}^{-1}\right)$, there were only ampoules of $5 \mathrm{~mL}$ with $5 \mathrm{mg}\left(1 \mathrm{mg} \cdot \mathrm{mL}^{-1}\right)$. It was in the case number four with stiffness that alerted us that another drug was implicated, but, how another drug could have reached the syringe of midazolam? Furthermore, the rapid onset effects do not correspond with midazolam, (because full effect is near three to five minutes), moreover the apnea is slow in the time. We considered that an opioid was implicated and the most likely was the remifentanil, for the rapid onset of action with apnea and stiffness. We were in presence of a drug error, and we had to check over the preparation of dilution of remifentanil for intraoperative analgesia. In the department, we usually prepare dilution of remifentanil with a syringe of $5 \mathrm{~mL}$ for dilution of $15 \mathrm{mg}$ of remifentanil $\left(3000 \mu \mathrm{g} \cdot \mathrm{mL}^{-1}\right)$. This $15 \mathrm{mg}$ of remifentanil were mixed in $250 \mathrm{~mL}$ of saline for a final concentration of $60 \mu \mathrm{g} \cdot \mathrm{mL}^{-1}$. In the same syringe of
$5 \mathrm{~mL}$ and without cleaning or discard it, the dilution of midazolam for premedication was prepared: $1 \mathrm{mg} \cdot \mathrm{mL}^{-1}$. In the last syringe, if it only remains $0.1 \mathrm{~mL}$ in the syringe there would be $300 \mu \mathrm{g}$ of remifentanil. This amount diluted with $5 \mathrm{~mL}$ of the midazolam results in a final concentration of $50 \mu \mathrm{g} \cdot \mathrm{mL}^{-1}$, but total amount of remifentanil in the syringe remains unknown, albeit still high for a bolus of this opioid.

Remifentanil is an esterase-metabolized opioid, it has a small volume of distribution, a rapid distribution phase, a terminal elimination half-life of 3 to $10 \mathrm{~min}$, and half-time for equilibration between plasma and effective compartment of $1.3 \mathrm{~min}$ with a rapid clearance.

The incidence of side effects: muscle rigidity, respiratory depression and apnea are all related to the dose and rate of administration. Therefore, boluses should be administered slowly, over 60 seconds (not recommended for cardiac anesthesia $)^{5}$.

In the anesthesia daily routine, safe management of patients is as important as or even more than the accurate drug administration. Despite this, drug error remains a hazard to patients everywhere. In a 1984 further critical-incident analysis published by Cooper el al. ${ }^{6}$, the most frequently cited critical incident category was breathing circuit disconnection and the next categories included both syringe swap and ampoules swap. In the study of Orser et al. ${ }^{7}$ an anonymous survey in 1995, there were 1,038 drug related events. Fifteen of the errors $(1.4 \%)$ resulted in major morbidity (including 4 deaths). In a similar survey in Australia ${ }^{8}, 89 \%$ of respondents admitted having made at least 1 drug error. However, no such systematic innovations have yet been widely adopted to reduce medication error. It is impossible to address drug error effectively without addressing the organizational culture of anesthesia ${ }^{9}$. Many would regard it as a not acceptable practice in 2009 because new clean syringe should be used for every different drug or only one syringe for every drug. In the cases described, the same syringe was used to prepare and dilute two different drugs. The error was therefore caused by the presence of the second drug. Today, in the twenty-first century though errors are still happening.

The first measurement to establish a suitable prevention is to admit that to error is of human nature. That is to say that independently of the training and of the care of the people, the mistakes can happen in any human process. Also it is necessary to admit that failures exist in the system and not for incompetence or human mistake. In consequence, to punish or to eliminate the responsible of the mistake is not going to modify the latent faults of the system and it is probable that the same mistake could happen again. Definitively, which is interesting is to analyze the mistake to identify how, where and why it has been produced.

In a study about prevention of Leape et al. ${ }^{10}$ the most frequent detected reasons were the lack of knowledge on the medicine (22\% of the mistakes) and the lack of information about the patient (14\% of the mistakes). The failure of the most common system was the incorrect diffusion of information about medicines, particularly to doctors, failure which they attributed $29 \%$ of the mistakes analyzed, followed by an inadequate 
availability of information about the patient that was associated with $18 \%$ of the mistakes. Seven of 16 failures of the system explained practically $80 \%$ of the mistakes, and all of them were related to problems of access to the information.

This way, the aim for the reduction of the EM in the operation theaters implies to establish a systematic organization of the drug drawers and workspace should be used with attention to tidiness, position of ampoules and syringes, separation of similar or dangerous drugs, removal of dangerous drugs, together with the detection and analysis of the $\mathrm{EM}^{11,12}$.

In order to get it, and thinking about our experience, we believe that: firstly, systems of communication of effective mistakes have to be done, secondly there is to design a few systems that prioritize the safety in the prevention of the mistakes with drugs at the same time as they are self-evaluated to modify them according to new detected failures. Finally, the hospitals must include inside their management of risks, the risk of EM integrated to a suitable plans of continued training to offer information and periodic preparation.

\section{REFERÊNCIAS - REFERENCES}

1. Yamamoto $M$, Ishikawa $S$, Makita $\mathrm{K}$ - Medication errors in anesthesia: an 8-year retrospective analysis at an urban university hospital. $J$ Anesth, 2008;22:248-252.

2. Fasting S, Gisvold SE - Adverse drug errors in anesthesia, and the impact of coloured syringe labels. Can J Anaesth, 2000;47:1060-1067.

3. Webster CS, Merry AF, Larsson L et al. - The frequency and nature of drug administration error during anaesthesia. Anesth Intensive Care, $2001 ; 29: 494-500$.

4. Bowdle TA - Drug administration errors from the ASA Closed Claims Project. ASA Newsletter, 2003;67:11-13.

5. Anesthesia UK: Remifentanil. Disponível em: http://www.frca.co.uk/ SectionContents. Aspx?sectionid=168. Acessado em maio/2009.

6. Cooper JB, Newbower RS, Kitz RJ - An analysis of major errors and equipment failures in anesthesia management: considerations for prevention and detection. Anesthesiology, 1984;60:34-42.

7. Orser BA, Chen RJB, Yee DA - Medication errors in anesthetic practice: a survey of 687 practitioners. Can J Anaesth, 2001;48:139-146.

8. Abeysekera A, Bergman IJ, Kluger MT et al. - Drug error in anaesthetic practice: a review of 896 incidents from the Australian Incident Monitoring Study database. Anaesthesia, 2005;60:220-227.
9. Woods I - Making errors: admitting them and learning from them Anaesthesia, 2005;60:215-217.

10. Leape LL, Bates DW, Cullen DJ et al. - Systems analysis of adverse drug events. ADE Prevention Study Group. JAMA, 1995;274:35-43.

11. Runciman WB - latrogenic harm and anaesthesia in Australia. Anaesth Intensive Care, 2005;33:297-300.

12. Jensen LS, Merry AF, Webster CS et al. - Evidence-based strategies for preventing drug administration error during anaesthesia. Anaesthesia, 2004;59:493-504

\section{RESUMEN}

LLagunes Herrero J, Reina C, Blasco L, Fernandez E, Plaza M, Mateo E - Errores de Medicación en la Práctica de la Anestesia: Cuatro Casos de Morbilidad no Fatal.

\section{JUSTIFICATIVAS Y OBJETIVOS:}

Los anestesiólogos están cada vez más preocupados sobre la seguridad de los pacientes, haciendo un gran énfasis en los resultados, en la cualidad de los cuidados en la salud, como también en el quirófano o en cualquier otro lugar dentro del hospital. En la práctica clínica, no existe un aspecto de la anestesia que sea más crucial en el aspecto del cuidado de la seguridad de los pacientes, que no sea la correcta administración de los fármacos. Los errores en la medicación representan una pequeña parte de los problemas de la anestesia pero todavía son un serio problema para la morbilidad, como también traen serias consecuencias legales. El objetivo de este artículo, fue describir cuatro casos de unos inusuales errores médicos (EM) en el quirófano, sin perjudicar al paciente y verificando cómo sus análisis e identificaciones pueden prevenir daños más serios.

REPORTE DE CASOS: Cuatro casos de sobre dosis inadvertida en quirófano antes de la inducción de anestesia. Se usó la misma jeringuilla para la preparación y la dilución de dos fármacos diferentes. Por lo tanto, el error fue causado por la presencia del segundo fármaco. La toxicidad se manifestó con depresión y sedación temporales, necesitando ventilación asistida, no habiendo sido registrados resultados adversos.

\section{CONCLUSIONES}

Hemos explicado cómo identificar los fármacos involucrados, y el punto en que ocurrió el error, en el sentido de perfeccionar la práctica clínica reduciendo los errores médicos. Nos concentramos en proveer más información y más educación de literatura médica sobre los nuevos fármacos y sobre sus procesos de preparación a cada médico, porque ésa no es una práctica aceptable en el 2009. 